\title{
Administrative permitting activities in town planning
}

\author{
Elena Voskresenskaya ${ }^{1 *}$, Lybov Vorona-Slivinskaya ${ }^{2}$, Yury Kazakov $^{2}$ and Anton Zernov ${ }^{1}$ \\ ${ }^{1}$ Peter the Great St.Petersburg Polytechnic University, 29 Polytechnicheskaya str., St. Petersburg, \\ 195251, Russia \\ ${ }^{2}$ Saint Petersburg State University of Architecture and Civil Engineering, 4, 2nd Krasnoarmeyskaya \\ str., St. Petersburg, 190005, Russia
}

\begin{abstract}
The article is focused on current issues concerning administrative permitting activities, which are the part of administrative activity as a whole. The field of town planning involves the interests of both business entities and people living in a particular territory. Economic development demands the effective regulation in order to attract investment in the construction sector, while people's interest calls for fulfilling the principle of sustainable development of a territory. Thus, the administrative statutory regulation must on the one hand imply diminishing administrative burdens in order to provide the transparency and promptness of passing regulative procedures, and on the other hand be sufficient for ensuring the safety and appropriateness of development of a territory. Construction is one of vital and the most complicated sectors of the economy that is primarily aimed at providing people with residential property. To erect a residential building one needs high-quality communication lines, transport and social infrastructure. Construction of industrial parks, maintenance of existing industrial areas and transport infrastructure facilities and creation of new ones, providing people living in dilapidated dwellings with new residential space, housing resource renewal - these are the first key tasks for the authorities today. The circumstances mentioned above entail the demand for efficient administrative control over town planning sector. In this regard, the scientific comprehension of the term "administrative permitting activities" can raise the level of understanding all management processes running on the economy system, as well as the issues of exercising the powers conferred to executive public bodies acting in the related field.
\end{abstract}

\section{Introduction}

Addressing to the problems of legal regulation of permitting activities in town planning, that is one of the most important areas of public administration, is an urgent issue, which being solved is intended to provide both further development of theoretical basis for the mechanism of administrative permitting activities in town planning and the improvement of legal norms, on the basis of which this mechanism works.

\footnotetext{
*Corresponding author: elenvoskr@mail.ru
} 
Currently, domestic science has no comprehensive monographical studies of the problems of administrative permitting activities in the field of town planning in the Russian Federation.

General issues of public administration and administrative regulation in the field of town planning are considered by individual scientists [1-2]. Problems of administrative responsibility in the construction industry are also the subject of certain researches [3-9]. In recent years, the conceptual apparatus regarding licensing activities has been supplemented with a new term - "administrative approval", which was introduced into scientific language in the context of ensuring security in the Russian Federation [10]. Certain types of administrative permitting activities were considered in writings of the authors of the present article [11-14]. Noting the contribution of scientists to the formation of scientific ideas about various forms of implementation of administrative permitting activities, it is worth mentioning that these activities have never been a subject for special scientific research in terms of town planning. In this regard, it can be concluded that today there is a gap in scientific examination of the institute of administrative permitting activities in town planning, so the present paper is aimed to fill up this gap within the limits indicated by the goals and tasks of the study.

\section{Materials and methods}

The research methodology is based on both general and individual scientific cognition methods: dialectical, historical, linguistic, systemic, synthesis, analysis, formal-and-logical, legal modeling, comparative legal, inter-branch, method of studying legal phenomena.

The legal basis for the research involves the norms of national law that determine permitting activities, in the field of town planning as well. The documents that have been examined include: the Constitution of the Russian Federation, the Town Planning Code of the Russian Federation, the Land Code of the Russian Federation, the Federal Laws "On Technical Regulation" and "Technical Regulation on the Safety of Buildings and Structures", regulatory legal acts of federal, regional and local levels, including administrative standing orders, national and regional development programs, land use and development rules of settlements and urban districts, that are in force in different constituent entities of the Russian Federation.

The empirical basis of the research includes the results of assessing statistical data on the place that construction industry takes in the country's economy, as well as on the level of administrative barriers' spread in construction, on documentation regarding territorial planning, urban development zoning and laying-out of territories of the Russian Federation or individual constituent entities, on enforcement materials of executive authorities and local government bodies related to the application of administrative permitting measures in the field of town planning in the form of approval, accreditation, judicial practice in cases on contesting decisions and actions (or inactions) of executive authorities or local government bodies related to issuing special permits in the field of town planning.

The objective of the study is to develop theoretical principles characterizing the institution of administrative permitting activities in town planning, as well as standards aimed at improving legal regulation of town planning.

\section{Results}

Administrative permitting activities are a type of administrative activities consisting of a set of relevant administrative actions and implemented through appropriate administrative procedures. The goals of administrative permits are to provide the realization of the rights 
and legal interests of an applicant, to ensure the legality of the actions (activities) of an applicant, as well as the development, stability and security of public relations, and to prevent harm to public relations protected by law.

Measures of permitting activities are understood as specific types and methods of influence used by administrative bodies to achieve the goals of permitting activities, the main content of which is to assess the correspondence of actions (activities), the condition of property (objects) belonging to a permit applicant, his legal and organizational-and-technical situation to the requirements of regulatory legal acts.

The author considers the following types and methods of influence as the administrative permitting measures:

1) licensing of certain types of activities;

2) the issuance of special permits for the implementation of certain actions, the use of individual objects;

3) state accreditation of citizens and organizations;

4) state certification of citizens and organizations;

5) mandatory product certification;

6) state registration of persons, rights, objects;

7) state examination of individual objects, certain types of documents (documentation), the implementation of certain types of activities and the issuance of an expert opinion. According to the World Bank rate "Doing business", Russia takes 156th place by the category "Obtaining building permits" (table 1) [15].

Table 1. The World Bank rate «Doing business» by the category "Obtaining building permits"

\begin{tabular}{llrrr}
\hline $\begin{array}{c}\text { Place } \\
\text { number }\end{array}$ & \multicolumn{1}{c}{ Country } & $\begin{array}{c}\text { Procedures } \\
\text { (amount) }\end{array}$ & Term (days) & $\begin{array}{c}\text { Cost (\% of } \\
\text { income per } \\
\text { capita) }\end{array}$ \\
\hline 1 & Hong Kong, China & 5 & 66 & 0.4 \\
2 & Singapore & 10 & 26 & 0.3 \\
3 & Georgia & 8 & 68.5 & 0.3 \\
5 & Denmark & 7 & 64 & 2.3 \\
6 & Thailand & 7 & 113 & 0.1 \\
8 & Germany & 8 & 96 & 1.1 \\
17 & The United Kingdom & 9 & 105 & 1.2 \\
18 & Sweden & 7 & 116 & 2.4 \\
19 & Australia & 10 & 112 & 0.5 \\
20 & Estonia & 11 & 103 & 0.3 \\
21 & Saudi Arabia & 11 & 102 & 0.4 \\
22 & Vietnam & 10 & 114 & 0.7 \\
33 & Finland & 15 & 64 & 0.8 \\
156 & Russia & 19.8 & 238.4 & 1.9 \\
184 & India & 25.4 & 185.9 & 28.2 \\
185 & Afghanistan & 11 & 323 & 57.4 \\
186 & Serbia & 16 & 264 & 25.7 \\
\hline
\end{tabular}

According to the Ministry of Construction and Housing and Utility Services of the Russian Federation, as of December 1, 2019, 1,116 building permits were issued, as well as 1,001 commissioning permits, the amount of persons certified for the right to prepare examination reports on design documentation and (or) on engineering survey results was 14,949 [16]. Preliminary results of work in 2019 are as follows: for 11 months, the Federal Autonomous Institution "Main Directorate of State Expert Review" issued 5,651 expert reports, $18 \%$ of which were negative. At the same time, during the examination of design documentation and engineering survey results, the experts educed some wrong decisions that could lead to the risk of emergencies. 798 sets of documentation, which is $26 \%$ of the 
total amount, contained such errors. The total share of reports on facilities regarding transportation construction, oil and gas industry and facilities designed for housing and civil purposes amounted approximately $85 \%$. Among the reports on facilities of transportation construction, $53 \%$, which is more than a half, are the reports on facilities related to railways. Among the reports on facilities regarding the oil and gas industry - 59\% of the facilities are designed for the development of oil, gas and gas condensate fields. Statistics is presented in table 2 (Figure 1) [17].

Table 2. Statistics of Federal Autonomous Organization «Glavstroyexpertiza» for 2015-2018

\begin{tabular}{|c|c|c|c|c|}
\hline Indicators & 2015 & 2016 & 2017 & 2018 \\
\hline $\begin{array}{l}\text { Structure of reports by type of } \\
\text { service in total, } \% \text {, including }\end{array}$ & 100.0 & 100.0 & 100.0 & 100.0 \\
\hline $\begin{array}{l}\text { state examination of design } \\
\text { documentation and engineering } \\
\text { survey results }\end{array}$ & 77.0 & 78.0 & 69.0 & 54.0 \\
\hline verification of estimates & 23.00 & 22.0 & 31.0 & 46.0 \\
\hline $\begin{array}{l}\text { Structure of the volumes of reports } \\
\text { on a result, total, } \% \text {, including }\end{array}$ & 100.0 & 100.0 & 100.0 & 100.0 \\
\hline positive reports & 80.0 & 80.0 & 83.0 & 84.0 \\
\hline negative reports & 20.0 & 20.0 & 17.0 & 16.0 \\
\hline $\begin{array}{l}\text { Share of facilities financed } \\
\text { involving federal budget, } \%\end{array}$ & 32.0 & 35.0 & 31.0 & 29.0 \\
\hline $\begin{array}{l}\text { Savings from the federal budget } \\
\text { according to the results of the } \\
\text { verification of the estimated cost of } \\
\text { facilities financed involving federal } \\
\text { budget, billion rubles }\end{array}$ & 299.9 & 295.7 & 141.9 & 118.1 \\
\hline $\begin{array}{llll}\text { Percentage } & \text { of } & \text { reduction in } \\
\text { estimated } & \text { cost } & \text { of } & \text { capital } \\
\text { construction } & & & \end{array}$ & 18.9 & 19.6 & 9.5 & 8.1 \\
\hline $\begin{array}{l}\text { Number of reports of the state } \\
\text { examination of design } \\
\text { documentation issued in relation to } \\
\text { facilities, technical solutions of } \\
\text { which, if implemented, could lead } \\
\text { to the risk of emergencies, units }\end{array}$ & 1049 & 908 & 883 & 875 \\
\hline $\begin{array}{l}\text { in } \% \text { of total number of reports of } \\
\text { the state examination of design } \\
\text { documentation }\end{array}$ & 22 & 22 & 24 & 24 \\
\hline
\end{tabular}




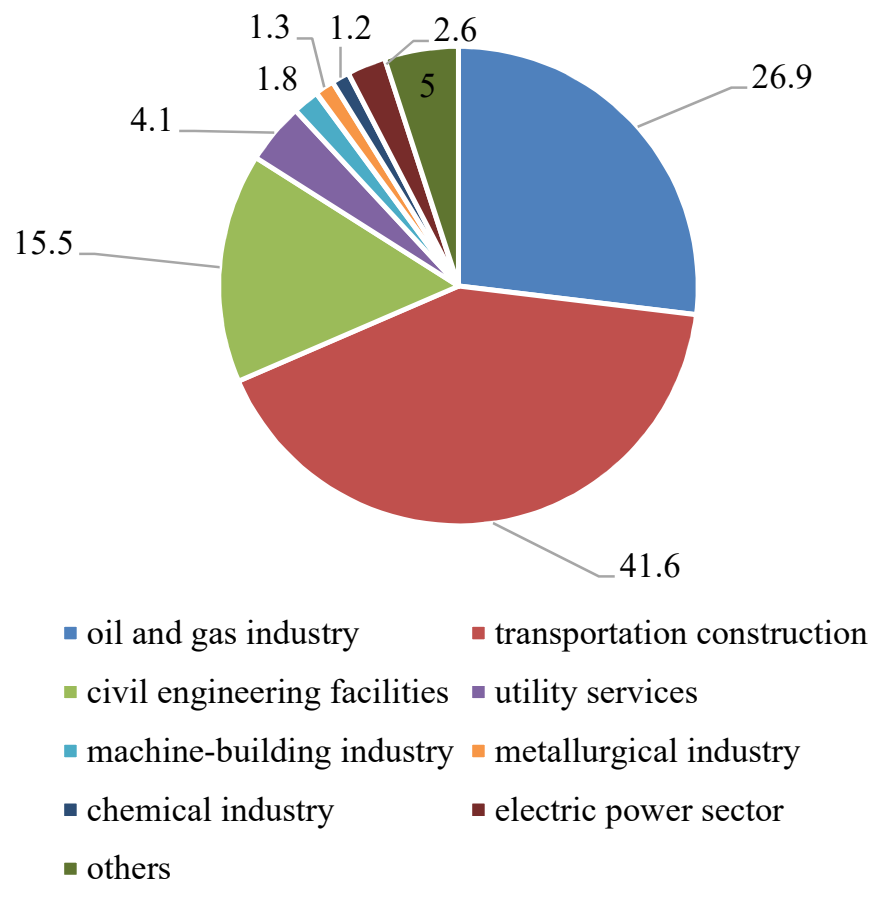

Fig. 1. Structure of values of reports regarding to industry sector of facility in 2018

\section{Discussion}

The ongoing administrative reform is aimed at eliminating excessive administrative barriers in the construction sector. At the same time, administrative and permitting activities are aimed to find and ensure the balance between the necessary governmental or public interference into the construction industry and the freedom of construction relations parties. The authors assume that administrative permitting activities in the field of town planning should become a sufficient and effective legal tool for regulating urban development relations, yet without creating unnecessary obstacles for participants of these relations.

When characterizing the administrative permitting activities in the field of town planning, their following features should be highlighted:

- The specifics of a set of parties interested in its implementation. Such parties are usually entities interested in construction, reconstruction or overhaul of various capital construction facilities.

- Occurrence in stages, depending on a stage of the process of town planning.

- A certain set of administrative bodies and their subordinate institutions, as well as other organizations authorized to carry out administrative and permitting activities in this area.

- The special social significance of administrative permitting activities, that is conditioned by a high degree of public danger of relations in the construction sector and the need to take into account the balance of public and private interests.

\section{Conclusions}


The authors propose a classification of measures for administrative permitting activities in town planning, which are proposed to contain: 1) administrative provision of a land plot for building a capital construction facility; 2) granting permission for a conditionally permitted type of use of a land plot; 3) providing permission to deviate from the maximum permissible construction parameters; 4) examination of the results of engineering surveys and (or) design documentation; 5) accreditation of legal entities for the right to conduct a non-state examination of project documentation and (or) non-state examination of the results of engineering surveys; 6) certification of individuals for the right to prepare expert reports on the results of engineering surveys and (or) design documentation; 7) issuance of a permit for the construction (reconstruction) of a capital construction facility; 8) issuance of a permit for commissioning a capital construction project completed by construction (reconstruction); 9) state accreditation of self-regulatory organizations operating in the town planning sector; 10) state registration of hazardous production facilities - sites for the operation of lifting structures (mechanisms).

At the stage of providing land plots for erecting a capital facility, the content of administrative permitting activities (administrative approval) is giving by a competent executive authority or local government of approval (or disapproval) of providing an individual or legal entity with a chosen land for construction purposes and for the further placement of a capital construction facility. The approval (or disapproval) is implemented through publication (adoption) of a relevant administrative act (decision, regulation).

At the stage of engineering surveys and architectural and construction design, administrative permitting activity (administrative approval) consists in the official assessment of compliance with mandatory requirements to engineering surveys and design documentation through state and non-state examination by authorized organizations in accordance with the law in order to further obtain a permit for construction (reconstruction) of a capital facility.

At the stage of construction itself, administrative permitting activity (administrative approval) consists in issuing (or refusing to issue) a permit for the construction (reconstruction) of a capital facility by a competent executive authority or local government in order to create a legal opportunity for the necessary construction and installation works. At the stage of commissioning a facility completed by construction or reconstruction, administrative and permitting activity (administrative approval), consists in issuing (refusal to issue) a permit to commission the constructed (reconstructed) capital facility.

To ensure the safety of construction and further operation of facilities, it is advisable to consolidate in article 51 of the Town Planning Code of the Russian Federation [18] the rules on the need for a developer to send notifications to administrative and public authorities about the start of construction of those types of objects, which do not require receiving a permission, with simplifying the relevant town planning procedures (without working out design documentation and performing surveys, without examination of mentioned documents), with further simplified state construction supervision (by means of monitoring the construction of a facility).

Standards of the special legislation of the Russian Federation provide for the need to obtain approvals regarding the allowance of erecting a specific capital facility in certain types of territories or land plots from the competent state bodies and other organizations. In this regard, the authors have substantiated the idea to supplement article 51 of the Town Planning Code of the Russian Federation with a rule that obligates an administrative public body (after an applicant sent an application and documentation which is necessary for obtaining a building permit) to independently obtain the approval regarding the allowance to build a specific capital facility from the competent state bodies and other organizations in cases, when restrictions can be set on the use of certain types of territories and land plots for the erection and placement of facilities.

\section{References}


1. A.V. Erchov, Urban development management in Russia: administrative and legal aspect, (2017)

2. S.A. Kuznetsova, Administrative and legal regulation in the field of construction (2015)

3. N.V. Trubkin, Preparation and approval of urban planning documentation of settlements, urban districts (2011)

4. F.N. Kiselev, Administrative authorization as a method of ensuring security in the Russian Federation (2011)

5. A.V. Ivanov self-Regulation of construction activity: development, issues, solutions, 11, 18-22 (2013)

6. S.S. Kupreev, Licensing as an administrative and legal method of public administration: current state, 4, 18-21 (2013)

7. A.S. Malchinov, Effective interaction of Federal public authorities and public authorities of the subjects of the Russian Federation-a factor of successful regional policy of Russia. URL: http://problemanalysis.ru/naukadoklad/malchinov.pdf

8. A.V. Nesterov, Accreditation as an administrative and legal tool, 1, 22-26 (2013)

9. D.A. Petrov, Concept and signs of self-regulation as a legal phenomenon, 20, 89-112 (2013)

10. A.I. Stakhov, Administrative and public security in the Russian Federation (2011)

11. E. Voskresenskaya, V. Snetkov, A. Tebryaev, E3S Web of Conferences, 33, 03051 (2018). doi.org/10.1051/e3sconf/20183303051

12. E.Voskresenskaya, V. Snetkov, A. Tebryaev, Z. Askarov, MATEC WEB OF CONFERENCES, 10, 08055 (2017). https://doi.org/10.1051/matecconf/201710608055

13. P.K. Sun, L. Vorona-Slivinskaya, E. Voskresenskaya, IOP Conference Series: Earth and Environmental Science, 90 (2017) https://doi.org/10.1088/1755-1315/90/1/012073.

14. E. Voskresenskaya, N. Zhilskiy and E. Shariapova, MATEC Web of Conferences, 170, 01057 (2018) https: //doi.org/10.1051/matecconf/201817001057

15. World Bank rating "Doing business» in the category» Obtaining a construction permit» // https://www.minstroyrf.ru/opendata/7707780887-doingbusiness/

16. Ministry of construction and housing and communal services of the Russian Federation // https://www.minstroyrf.ru

17. Statistics of the Federal Autonomous institution «Gastrotoxicity» // https://gge.ru/analytics/statistika-po-godam/

18. Urban planning code of the Russian Federation 